\title{
Identification of Weed Hosts of Tomato yellow leaf curl virus in Cyprus
}

L. C. Papayiannis, Agricultural Research Institute, P.O. Box 22016, Nicosia 1516 Cyprus; N. I. Katis, Aristotle University of Thessaloniki, Faculty of Agriculture, Plant Pathology Laboratory, 54 124, Thessaloniki, Greece; and A. M. Idris and J. K. Brown, School of Plant Sciences, The University of Arizona, Tucson 85721

\begin{abstract}
Papayiannis, L. C., Katis, N. I., Idris, A. M., and Brown, J. K. 2011. Identification of weed hosts of Tomato yellow leaf curl virus in Cyprus. Plant Dis. 95:120-125.

An extensive study was conducted during 2007 and 2008 in three major tomato production areas of Cyprus, where Tomato yellow leaf curl virus (TYLCV) is commonly found, to assess the incidence and prevalence of naturally infected weed species that could serve as TYLCV reservoirs. Approximately 4,000 of the most common dicotyledonous plants belonging to 122 species from 25 families were collected, identified, and tested for TYLCV presence using serological and molecular methods. The tests included a previously reported conventional polymerase chain reaction (PCR) assay and a real-time TaqMan PCR assay developed and optimized in this study. Real-time PCR was found

to be the most sensitive technique, and enabled the detection of TYLCV in 461 samples of 49 different species belonging to the families Amaranthaceae, Chenopodiaceae, Compositae, Convolvulaceae, Cruciferae, Euphorbiaceae, Geraniaceae, Leguminosae, Malvaceae, Orobanchaceae, Plantaginaceae, Primulaceae, Solanaceae, Umbelliferae, and Urticaceae. The results further indicated that the host range of TYLCV in Cyprus is far more extensive than previously documented and, therefore, new management strategies are required. These should focus on the control of alternative virus hosts during the growing season and in crop-free periods.
\end{abstract}

Tomato yellow leaf curl disease (TYLCD) is one of the most devastating virus diseases of tomato (Lycopersicon esculentum) crops worldwide, causing significant crop losses in many tropical, subtropical, and temperate regions $(1,11)$. Several viruses have been associated with this disease, all assigned to the genus Begomovirus, family Geminiviridae. At least four virus species are associated with epidemics in the countries neighboring the Mediterranean Sea: Tomato yellow leaf curl virus (TYLCV), Tomato yellow leaf curl Sardinia virus (TYLCSV) (1), and the recently reported recombinant species Tomato yellow leaf curl Malaga virus (TYLCMalV) (36) and Tomato yellow leaf curl Axarquia virus (TYLCAxV) (16). The viruses are transmitted by the sweet potato whitefly Bemisia tabaci (Hemiptera: Aleyrodidae) in a persistent manner $(8,9)$.

The disease was first identified in Israel during the 1960s (10). In Cyprus, TYLCV-like symptoms were first observed in 1974 on tomato crops grown on the southeastern part of the island and have since appeared in all vegetable-producing regions (18). TYLCV outbreaks have become a serious economic problem on the island and the disease is currently the primary limiting factor in both open-field and greenhouse tomato production. Infected tomato plants show characteristic upward cupping, distortion and interveinal yellowing of leaves, severe stunting, degeneration, and flower abortion. These symptoms often lead to substantial yield losses, especially if the plants are infected at an early growth stage $(4,9,18)$. To date, TYLCV is the only Begomovirus reported to infect tomato crops in Cyprus (26) vectored by the B and Q biotypes of B. tabaci (27).

In the Mediterranean region, TYLCV has also been reported to infect other cultivated hosts, including common bean (Phaseolus vulgaris) $(23,28)$ and pepper (Capsicum annuum and C. chinensis) (30). Also, many weed plants have been found to be infected with TYLCV worldwide, the majority of which exhibit no symptoms.

Corresponding author: L. C. Papayiannis

E-mail: 1.papayiannis@arinet.ari.gov.cy

Accepted for publication 17 October 2010.

doi:10.1094/PDIS-05-10-0346

(C) 2011 The American Phytopathological Society
These species are mainly reported within the families Amaranthaceae, Ascleridaceae, Chenopodiaceae, Convolvulaceae, Euphorbiaceae, Solanaceae, Compositae, Malvaceae, Plantaginaceae, Leguminosae, and Umbelliferae (5,15,16,19-21,25,31,34). It is assumed that weeds harbor the virus as alternate hosts that can serve as reservoirs, potentially influencing the epidemiology and spread of TYLCV, primarily during crop-free periods $(7,17,33)$. The aim of this study was to investigate the prevalence of TYLCV in weeds and to identify the most important endemic and introduced noncultivated host species of TYLCV within and near TYLCV-infected tomato fields. To identify the virus in field-collected weeds, three types of assays were used and comparedenzyme-linked immunosorbent assay (ELISA), conventional and real-time polymerase chain reaction (PCR), and positive results were verified by sequencing analysis.

\section{Materials and Methods}

Prevalence and incidence of TYLCV in weeds. Weed species were sampled during 2007 and 2008 in three major tomato-production areas located along the island's coastal regions of Sotera $\left(35^{\circ}\right.$ $\left.01^{\prime} \mathrm{N}, 33^{\circ} 56^{\prime} \mathrm{E}\right)$, Kiti ( $\left.34^{\circ} 50^{\prime} \mathrm{N}, 33^{\circ} 34^{\prime} \mathrm{E}\right)$, and Parekklisia ( $34^{\circ}$ $44^{\prime} \mathrm{N}, 33^{\circ} 09^{\prime} \mathrm{E}$ ), where the incidence of TYLCD symptoms has been high (80 to $100 \%$ ) in tomato crops since 2000 (26). In total, 3,976 of the most common dicotyledonous plants belonging to 122 species from 25 families were randomly collected, placed in plastic bags, and identified at the Laboratory of Weed Science Section of Cyprus Agricultural Research Institute (ARI). The weed samples were identified to species level and inspected for the presence of virus-like symptoms. All weed samples were then washed well with distilled water to remove any whitefly honeydew, and the youngest fully developed leaves or stems were divided into three samples and placed separately into plastic bags, two of which were processed within 1 to 3 days and subjected to serological and molecular detection. The third subsample was archived at $-80^{\circ} \mathrm{C}$ for further study, if warranted.

Serological tests. All samples were analyzed by triple-antibody sandwich (TAS)-ELISA using a TYLCV kit supplied by NEOGEN Europe according to the manufacturer's directions. Leaf tissue from TYLCV-infected and virus-free tomato plants were used in all tests as a positive and negative control, respectively. ELISA reaction results were recorded using a Jenway 640 S UV/Vis Spectrophotometer at $405 \mathrm{~nm}$. A sample was considered virus positive if 
the optical density (OD) at an absorbance value of $405 \mathrm{~nm}$ was greater than twice the average values of samples from healthy plant extracts.

DNA extraction. Total DNA was extracted from leaf samples using a previously reported, modified method (12). Briefly, samples of $0.5 \mathrm{~g}$ of leaf tissue were ground in $5 \mathrm{ml}$ of extraction buffer (50 mM EDTA, $100 \mathrm{mM}$ Tris- $\mathrm{HCl}, 500 \mathrm{mM} \mathrm{NaCl}, 10 \mathrm{mM}$ citric acid, and $1 \%$ sodium dodecyl sulfate), vortexed, and allowed to stand at $65^{\circ} \mathrm{C}$ for $10 \mathrm{~min}$. After adding one-fifth volume of potassium acetate ( $5 \mathrm{M}, \mathrm{pH} 8)$, the mixture was incubated on ice for 60 min and the cellular debris was precipitated by centrifugation at $13,000 \mathrm{rpm}$ for $20 \mathrm{~min}$ at $4^{\circ} \mathrm{C}$. An equal volume of isopropanol was added to the supernatant fraction and the mixture was then centrifuged for $10 \mathrm{~min}$ at 13,000 rpm. The pellet was resuspended, treated with $70 \%$ ethanol, allowed to air dry, and diluted in $80 \mu \mathrm{l}$ Tris-EDTA.

Conventional PCR test. PCR reactions were performed in a 25$\mu \mathrm{l}$ final volume containing $200 \mathrm{ng}$ of DNA, $10 \mathrm{mM}$ Tris- $\mathrm{HCl}, 50$ $\mathrm{mM} \mathrm{KCl}, 1.5 \mathrm{mM} \mathrm{MgCl}_{2}, 0.1 \%$ Triton X-100, $0.25 \mathrm{mM}$ each deoxyribonucleoside triphosphate, 1 unit Hot start Dynazyme II DNA Polymerase (Finnzymes, Espoo, Finland), and a final concentration of $1 \mu \mathrm{M}$ for primer AC923 and $0.5 \mu \mathrm{M}$ for primer AV632 (22). The PCR cycling profile consisted of a first step at $95^{\circ} \mathrm{C}$ for $10 \mathrm{~min}$ for enzyme activation; 35 cycles segmented in step $1,30 \mathrm{~s}$ at $94^{\circ} \mathrm{C}$, step $2,30 \mathrm{~s}$ at $59^{\circ} \mathrm{C}$, and step $3,30 \mathrm{~s}$ at $72^{\circ} \mathrm{C}$; followed by a final extension step at $72^{\circ} \mathrm{C}$ for $10 \mathrm{~min}$. Amplifications were carried out in a PTC 200 thermal Cycler (MJ Research, Inc., Waltham, MA) utilizing 0.2-ml thin-walled reaction tubes. DNA extracts from a TYLCV-infected and a virus-free tomato plant were used as positive and negative control, respectively. The reaction products were analyzed by electrophoresis in $1.5 \%$ agarose gels in $1 \times$ Tris-acetate EDTA buffer $(0.04 \mathrm{M}$ Tris-acetate, $0.001 \mathrm{M}$ EDTA), stained with ethidium bromide, and visualized under UV light.

TaqMan PCR assay design. A multiple sequence alignment of TYLCV isolates available from the National Center for Biotechnology Information database (AF058020, AB110218, AF105975, AF260331, AJ132711, AJ489258, EF185318, EF110890, EF060196, EF054893, AY594174, AY530931, AJ132711, $\mathrm{AB} 110218$, and AJ489258) was made using the CLUSTALW method (35). Conserved regions were identified and two primers, TYLCVF (5'-ACGCTTACGCCTTATTGGTTTC-3') and TYLCVR ( $5^{\prime}$-CGAGCCACTGTTCGCAAGT- $\left.3^{\prime}\right)$, as well as the TaqMan probe TYLCVTAQ (5'-[6-carboxyfluoresin, FAM]-TCT TGGCTATCTTGTGTTGGACCTTGATTGAT-[6-carboxytetramethulrhodamine, TAMRA]-3'), were used to amplify a 74-nucleotide (nt) fragment from the $\mathrm{C} 2$ gene. The probe was designed with a temperature value approximately $10^{\circ} \mathrm{C}$ higher $\left(70^{\circ} \mathrm{C}\right)$ than the primers $\left(60^{\circ} \mathrm{C}\right)$, with its length not exceeding $40 \mathrm{nt}$ or its percent GC content higher than $40 \%$. All primers and probes were supplied by MWG Biotech AG (Anzinger, Germany).

TaqMan PCR assay. The optimum primer concentration for the assay was determined from the five-by-five matrix of 50, 100, 300, 500 , and $600 \mathrm{nM}$ primer concentrations. The amount of primer which gave the highest reporter fluorescence and the lowest threshold cycle (CT; the cycle at which a significant increase of fluorescence occurs) was selected. The baseline threshold for this assay was analyzed using the positive and negative control samples and the critical upper CT value was estimated at 35 using the Bio-Rad iCycler IQ5 Manager software (Bio-Rad Laboratories, Inc., Hercules, CA). Therefore, all CT values below 35 were considered to be positive. The TaqMan reaction was performed in a final volume of $25 \mu$ containing $12.5 \mu \mathrm{l}$ of $2 \times$ IQ Supermix (Bio-Rad Laboratories, Inc.), $0.3 \mu \mathrm{M}$ each primer, $0.1 \mu \mathrm{M}$ TaqMan probe, and $2 \mu \mathrm{l}$ of template DNA. Cycling parameters consisted of $3 \mathrm{~min}$ at $94^{\circ} \mathrm{C}$ followed by 40 cycles of $15 \mathrm{~s}$ at $94^{\circ} \mathrm{C}$ and $60 \mathrm{~s}$ at $60^{\circ} \mathrm{C}$. The assay was developed and evaluated using the iCycler IQ5 Multicolor Real-Time PCR Detection System (Bio-Rad Laboratories, Inc.). CTs for a 10 -fold dilution series of $1 \mathrm{ng} / \mu \mathrm{l}$ of TYLCV plasmid DNA were plotted to yield a standard curve.
Sensitivity comparisons of serological and molecular tests. The relative sensitivity of the TaqMan PCR assay was compared with that of the conventional PCR and TAS-ELISA for TYLCV detection. For the comparison of the real-time and conventional PCR assays, $0.5 \mathrm{~g}$ of fresh symptomatic leaf tissue from tomato plants was ground in 10 volumes of DNA extraction buffer. From this extract, a 10 -fold dilution series was made in the range of $10^{-1}$ to $10^{-9}$ by diluting the infected sample with an extract made from healthy tomato plants ground in the same DNA extraction buffer. DNA was then extracted from the resulting dilution series and tested by TaqMan and conventional PCR. The sensitivity of ELISA in detecting TYLCV was determined using 10-fold dilution series of infected tomato extracts. The dilution series were prepared by adding $0.5 \mathrm{~g}$ from a TYLCV-infected tomato leaf into $5 \mathrm{ml}$ of ELISA extraction buffer (NEOGEN Europe) that was further diluted in the range of $10^{-1}$ to $10^{-9}$ in extracts from a healthy tomato sample. For each assay, (PCR-based and ELISA), the end-point dilution at which a positive result was obtained was recorded and used in comparisons.

Sequencing of PCR amplicons. The PCR fragments from all TYLCV-infected weed samples (340 bp for conventional PCR and $70 \mathrm{bp}$ for the TaqMan PCR-positive samples) were purified using the PureLink (Invitrogen Corporation, Carlsbad, CA) gel extraction system, and both strands were sequenced using the ABI PRISM BigDye Terminators v3.0 Cycling Sequencing Kit in an ABI automated sequencer (Applied Biosystems, Foster City, CA). The DNA sequencing data were analyzed and deposited in the GenBank database (Table 1). The sequences were compared for similarity against the nonredundant sequence database of the National Centre for Biotechnology Information, Bethesda, MD.

\section{Results}

Identification of weed species. In total, 122 different species representing 25 plant families collected from TYLCV-infected fields were identified and tested by serological and molecular tests. These species were Amaranthaceae: Amaranthus hybridus $(n=32$ plants tested), A. retroflexus $(n=63)$, A. viridis $(n=48)$, A. graecizans $(n=52)$, and A. albus $(n=24)$; Boraginaceae: Anchusa aegyptiaca $(n=26)$, A. humilis $(n=28)$, A. undulata $(n=22)$, Heliotropium europaeum $(n=38), H$. dolosum $(n=11)$, and $H$. supinum $(n=29)$; Capparaceae: Capparis spinosa $(n=35)$; Caryophyllaceae: Silene aegyptiaca $(n=21)$ and $S$. vulgaris $(n=$ 18); Chenopodiaceae: Chenopodium album $(n=62)$ and $C$. murale $(n=51)$; Compositae: Anthemis parvifolia $(n=46)$, A. rigida $(n=$ 31), Artemisia arborescens $(n=12)$, Asteriscus aquaticus $(n=45)$, Calendula arvensis $(n=137)$, Carduus pycnocephalus $(n=28)$, Carthamus dentatus $(n=15)$, C. tenuis $(n=10)$, Centaurea veneris $(n=14)$, Chrysanthemum coronarium $(n=66), C$. segetum $(n=$ 46), Cichorium spinosum $(n=16)$, Cirsium vulgare $(n=23)$, Conyza bonariensis $(n=35)$, Cynara scolymus $(n=10)$, Inula graveolens $(n=11)$, I. viscosa $(n=6)$, Lactuca serriola $(n=22)$, Matricaria recutita $(n=56)$, Onopordum cyprium $(n=13)$, Pallenis spinosa $(n=19)$, Senecio leucanthemifolius $(n=11), S$. vulgaris $(n=21)$, Silybum marianum $(n=18)$, Sonchus asper $(n=$ 31), S. oleraceus $(n=87), S$. tenerrimus $(n=20)$, Tragopogon sinuatus $(n=12)$, and Urospermum picroides $(n=25)$; Convolvulaceae: Convolvulus althaeoides $(n=21), C$. arvensis $(n=76), C$. humilis $(n=45)$, Cuscuta sp. $(n=7)$, and Ipomea stolonifera $(n=$ 11); Cruciferae: Brassica nigra $(n=2)$, B. oleraceae $(n=26)$, Capsella bursa-pastoris $(n=43)$, Erruca sativa $(n=7)$, Hirschfeldia incana $(n=21)$, Raphanus raphanistrum $(n=79)$, $R$. sativus $(n=18)$, Sinapis alba $(n=61)$, S. arvensis $(n=81)$, Sisymbrium irio $(n=11)$, and S. officinale $(n=8)$; Cucurbitaceae: Ecballium elaterium $(n=32)$; Euphorbiaceae: Chrozophora tinctoria $(n=$ 17), Euphorbia helioscopia $(n=17)$, and Mercurialis annua $(n=$ 7); Fumariaceae: Fumaria densiflora $(n=12)$, F. officinalis $(n=$ 28 ), and F. parviflora $(n=15)$; Geraniaceae: Erodium ciconium $(n$ =24), E. cicutarium $(n=19)$, E. moschatum $(n=7)$, Geranium dissectum $(n=5)$, and $G$. purpureum $(n=6)$; Labiatae: Lamium amplexicaule $(n=12)$; Leguminosae: Astragalus epiglottis $(n=$ 
19), Lens culinaris $(n=15)$, Lotus corniculatus $(n=11)$, L. edulis $(n=26)$ L. halophilus $(n=39)$, L. peregrinus $(n=10)$, Lupinus angustifolius $(n=3)$, Medicago sp. $(n=34)$, Melilotus albus $(n=$ $11), M$. indicus $(n=8), M$. sulcatus $(n=6)$, Scorpiurus muricatus $(n=81)$ Trifolium arvense $(n=15)$, T. hirtum $(n=12)$, and Vicia sp. $(n=27)$; Malvaceae: Althaea hirstuta $(n=19)$, Lavatera cretica $(n=26)$, L. punctata $(n=21)$, Malva cretica $(n=54), M$. neglecta $(n=178), M$. nicaeensis $(n=151), M$. parviflora $(n=$ $131)$, and M. sylvestris $(n=81)$; Orobanchaceae: Orobanche ramose $(n=17)$; Oxalidaceae: Oxalis corniculata $(n=25)$ and $O$. pes-caprae $(n=63)$; Plantaginaceae: Plantago coronopus $(n=$ 19), P. lagopus $(n=37), P$. major $(n=45)$, and $P$. maritima $(n=$ 17); Polygonaceae: Polygonum aviculare $(n=21), P$. convolvulus $(n=4)$, P. maritimum $(n=32)$, and Rumex dentatus $(n=28)$; Primulaceae: Anagallis arvensis $(n=82)$; Scrophullariaceae: Antir- rhinum majus $(n=14)$ and Veronica arvensis $(n=16)$; Solanaceae: Datura innoxia $(n=12)$, D. stramonium $(n=41)$, Solanum nigrum $(n=137), S$. villosum $(n=32)$, Solanum eleaegnifolium $(n=18)$; and Nicotiana glauca $(n=14)$ Umbelliferae: Scandix pecten-veneris $(n=33)$; Urticaceae: Parietaria judaica $(n=8)$, Urtica pilulifera $(n=26)$ and $U$. urens $(n=72)$; and Zygophyllaceae: Tribulus terrestris $(n=19)$.

Optimization of the TaqMan assay and sensitivity comparison between ELISA, conventional and real-time PCR. The concentration of primers that yielded the highest reporter fluorescence and the lowest CT was $300 \mathrm{nM}$ for both forward and reverse primers (data not shown). Following the primer optimization matrix, a concentration of $100 \mathrm{nM}$ of the TaqMan probe was selected for the assay. A standard curve based on threshold cycles for 10fold dilution series of plasmid DNA at $1 \mathrm{ng} / \mu \mathrm{l}$ containing the full-

Table 1. Incidence and detection efficiency of Tomato yellow leaf curl virus (TYLCV) in infected weed species in Cyprus

\begin{tabular}{|c|c|c|c|c|c|c|c|}
\hline \multirow[b]{2}{*}{ Family } & \multirow[b]{2}{*}{ Species $^{\text {a }}$} & \multirow[b]{2}{*}{ Life span ${ }^{b}$} & \multirow[b]{2}{*}{ Accession no. } & \multirow[b]{2}{*}{ Infected/tested $^{c}$} & \multicolumn{3}{|c|}{ Detection efficiency in virus-infected samples } \\
\hline & & & & & TAS-ELISA $^{d}$ & $\mathbf{P C R}^{\mathbf{e}}$ & Real-time PCR \\
\hline \multirow[t]{3}{*}{ Amaranthaceae } & Amaranthus retroflexus & A & FR682583 & $2 / 63$ & ND & ++ & 26 \\
\hline & Amaranthus viridis & A & FR682584 & $6 / 48$ & ND & ++ & 27 \\
\hline & Amaranthus graecizans & A & FN822919 & $8 / 52$ & ND & ++ & 28 \\
\hline \multirow[t]{2}{*}{ Chenopodiaceae } & Chenopodium album & A & FR682585 & $12 / 62$ & ND & + & 29 \\
\hline & Chenopodium murale & A & FN822920 & $9 / 51$ & ND & + & 29 \\
\hline \multirow[t]{12}{*}{ Compositae } & Asteriscus aquaticus & A & FR682586 & $10 / 45$ & 1.2 & ++ & 19 \\
\hline & Calendula arvensis & A & FN822921 & $37 / 137$ & 1.3 & +++ & 17 \\
\hline & Chrysanthemum coronarium & A & FR682587 & $12 / 66$ & ND & ++ & 21 \\
\hline & Chrysanthemum segetum & A & FR682588 & $6 / 46$ & ND & ++ & 18 \\
\hline & Conyza bonariensis & B & FR682589 & $5 / 35$ & ND & ++ & 25 \\
\hline & Matricaria recutita & A & FN822922 & $9 / 56$ & ND & + & 27 \\
\hline & Onopordum cyprium & A & FR681783 & $2 / 13$ & ND & - & 31 \\
\hline & Silybum marianum & B & FR681784 & $3 / 18$ & ND & - & 28 \\
\hline & Sonchus asper & A & FR682590 & $9 / 31$ & ND & ++ & 23 \\
\hline & Sonchus oleraceus & A & FN822923 & $14 / 87$ & ND & ++ & 25 \\
\hline & Sonchus tenerrimus & A & FR682591 & $2 / 20$ & ND & ++ & 22 \\
\hline & Urospermum picroides & A & FR682592 & $8 / 25$ & 1.1 & ++ & 20 \\
\hline \multirow[t]{3}{*}{ Convolvulaceae } & Convolvulus arvensis & $\mathrm{B}$ & FN822924 & $16 / 76$ & ND & +++ & 19 \\
\hline & Convolvulus humilis & $\mathrm{B}$ & FR682593 & $8 / 45$ & ND & +++ & 21 \\
\hline & Cuscuta spp. & A & FR682594 & $2 / 7$ & ND & + & 23 \\
\hline \multirow[t]{5}{*}{ Cruciferae } & Hirschfeldia incana & A & FR682595 & $1 / 21$ & ND & ++ & 24 \\
\hline & Raphanus raphanistrum & A & FR682596 & $18 / 79$ & ND & ++ & 22 \\
\hline & Raphanus sativus & A & FR682597 & $6 / 18$ & ND & ++ & 25 \\
\hline & Sinapis alba & A & FN822925 & $12 / 61$ & 1.1 & ++ & 21 \\
\hline & Sinapis arvensis & A & FR682598 & $11 / 81$ & 1.3 & ++ & 24 \\
\hline \multirow[t]{3}{*}{ Euphorbiaceae } & Chrozophora tinctoria & A & FN822926 & $2 / 17$ & ND & ++ & 22 \\
\hline & Euphorbia helioscopia & A & FR681785 & $4 / 20$ & ND & - & 30 \\
\hline & Mercurialis annua & A & FR681788 & $1 / 7$ & ND & - & 29 \\
\hline \multirow[t]{2}{*}{ Geraniaceae } & Erodium ciconium & A & FR682599 & $2 / 24$ & ND & ++ & 25 \\
\hline & Erodium cicutarium & A & FR682600 & $1 / 19$ & ND & ++ & 28 \\
\hline \multirow[t]{3}{*}{ Leguminoseae } & Lotus edulis & A & FR682601 & $5 / 26$ & ND & + & 30 \\
\hline & Lotus halophilus & A & FR682602 & $8 / 39$ & ND & + & 29 \\
\hline & Scorpiurus muricatus & A & FR682603 & $14 / 81$ & ND & ++ & 24 \\
\hline \multirow[t]{6}{*}{ Malvaceae } & Lavatera cretica & A & FR682604 & $3 / 26$ & 0.4 & ++ & 26 \\
\hline & Malva cretica & A & FR681786 & $8 / 54$ & ND & - & 28 \\
\hline & Malva neglecta & A & FR682605 & $30 / 178$ & 0.6 & ++ & 25 \\
\hline & Malva nicaeensis & A & FR682606 & $22 / 151$ & 0.6 & ++ & 26 \\
\hline & Malva parviflora & A & FN822927 & $19 / 131$ & 0.4 & ++ & 29 \\
\hline & Malva sylvestris & A & FR682607 & $11 / 81$ & 0.3 & ++ & 27 \\
\hline Orobanchaceae & Orobanche ramose & A & FR682608 & $3 / 17$ & ND & + & 26 \\
\hline \multirow[t]{2}{*}{ Plantaginaceae } & Plantago lagopus & A & FR682615 & $4 / 37$ & ND & ++ & 23 \\
\hline & Plantago major & A & FR682609 & $8 / 45$ & ND & ++ & 20 \\
\hline Primulaceae & Anagallis arvensis & A & FR682610 & $16 / 82$ & ND & + & 27 \\
\hline \multirow[t]{4}{*}{ Solanaceae } & Datura innoxia & A & FR682611 & $5 / 12$ & 1.7 & +++ & 18 \\
\hline & Datura stramonium & A & FR682612 & $18 / 41$ & 1.6 & +++ & 16 \\
\hline & Solanum nigrum & A & FN822928 & $28 / 137$ & 1.9 & +++ & 18 \\
\hline & Solanum villosum & A & FR682613 & $6 / 32$ & 1.5 & ++ & 22 \\
\hline Umbelliferae & Scandix pecten-veneris & A & FR682614 & $6 / 33$ & ND & ++ & 25 \\
\hline Urticaceae & Urtica urens & A & FR681788 & $9 / 72$ & ND & - & 31 \\
\hline
\end{tabular}

a Newly identified host species are given in bold.

${ }^{\mathrm{b}}$ Life span: $\mathrm{A}=$ annual and $\mathrm{B}=$ biennial.

${ }^{\mathrm{c}}$ Number of plants infected/tested using real-time polymerase chain reaction (PCR).

${ }^{d}$ Triple-antibody sandwich enzyme-linked immunosorbent assay (TAS-ELISA); mean optical density at $405 \mathrm{~nm}$; ND = not detected.

${ }^{\mathrm{e}}$ Band intensity in gel electrophoresis: $-=$ no amplified band, $+=$ barely visible band, $++=$ visible amplified band, and $+++=$ intense amplified band

${ }^{\mathrm{f}}$ TaqMan mean threshold cycle (CT) (lower CT = higher amplification efficiency). 
length TYLCV genome was constructed, illustrating the sensitivity and linearity of the technique. The TaqMan PCR slope was -3.34 , with a reaction efficiency of $99.4 \%$ estimated by the formula $\mathrm{E}=$ $\left[10^{-1 / \text { slope }}\right]-1$. The sensitivity of the real-time PCR was compared with that obtained by conventional PCR and TAS-ELISA for infected tomato samples. In a direct comparison, results showed that the TaqMan assay was more sensitive than the conventional PCR assay, detecting down to a dilution of $10^{-8} \mathrm{ng} / \mu \mathrm{l}$ DNA. In contrast, the dilution end point for the conventional assay in order to obtain a visible band in gel electrophoresis was $10^{-5} \mathrm{ng} / \mu \mathrm{l}$; therefore, the real-time PCR assay was approximately 1,000 times more sensitive (Fig. 1). Serological tests were able to detect TYLCV only to a dilution of $1: 10$.

Prevalence and incidence of TYLCV in weeds. Fourteen weed species in eight genera belonging to four families were found to be positive for TYLCV infection using the serological test (Table 1). The species Asteriscus aquaticus, Calendula arvensis, Urospermum picroides, Sinapis alba, S. arvensis, Datura stramonium, $D$. innoxia, Solanum nigrum, and $S$. villosum yielded the highest OD values, which were approximately 1.0. In contrast, ELISApositive samples of Lavatera cretica, Malva neglecta, M. nicaeensis, M. parviflora, and M. sylvestris showed a weak OD (0.3 to 0.6) reading at $405 \mathrm{~nm}$ (Table 1 ).

TYLCV was detected by conventional PCR in a large number of weed species found to be negative by ELISA tests. For example, Calendula arvensis, Convolvulus arvensis, D. stramonium, D. inoxia, S. nigrum, and S. villosum gave an intense amplification band in gel electrophoresis (Table 1). The majority of the PCR tests for positive samples, including Amaranthus sp., Asteriscus aquaticus, Chrysanthemum sp., Conyza bonariensis, Sonchus sp., Urospermum picroides, Hirschfeldia incana, Raphanus sp., Sinapis sp., Chrozophora tinctoria, Erodium sp., Scorpiurus muricatus, Lavatera cretica, Malva sp., Plantago sp., and Scandix pecten-veneris, yielded a visible PCR product of the expected size. PCR tests for samples of Chenopodium album, C. murale, Matricaria recutita, Cuscuta sp., Lotus edulis, L. halophilus, Orobanche ramose, and Anagalis arvensis produced faint PCR products (Table 1). Finally, Onopordum cyprium, Silybum marianum, Euphorbia helioscopia, Merculialis annua, Malva cretica, and Urtica urens failed to produce a PCR amplicon over multiple assays.
Compared with serological tests, the real-time (TaqMan) PCR assay provided the most sensitive and reliable results across all samples examined in this study and allowed the detection of TYLCV in six plant species that were believed to be nonhosts of the virus based on the serological assay and conventional PCR.

Sequencing analysis of the PCR products. Sequence analysis from at least one sample from each TYLCV-positive plant species was performed in order to verify the virus presence (Table 1). For weed species which were found to be positive using conventional PCR, a 340-bp amplicon was sequenced corresponding to the partial capsid protein gene. The DNA sequence was determined for a 70-bp PCR product for six samples that were only found to be positive using the real-time PCR assay. Sequencing analysis of all infected samples confirmed the presence of TYLCV. Data obtained from both conventional and TaqMan amplification showed that these isolates shared 99 to $100 \%$ nucleotide identity and were closely related to other TYLCV isolates from the Middle East (GenBank accession nos. X15656, EF051116, and EF054893).

Occurrence of TYLCV-symptoms in weeds. Virus-like symptoms, including yellowing and mild leaf curling, interveinal chlorosis, and vein clearing, were observed in only a small number of weed plants found to be positive to TYLCV. Leaf yellowing and curling was observed in 21 Solanum nigrum and 14 Datura stramonium TYLCV-infected plants (Fig. 2) whereas no symptoms were observed in TYLCV-negative samples. However, several asymptomatic S. nigrum (seven) and D. stramonium (four) plants were TYLCV positive based on the results of serological and PCRbased assays. Other symptoms such as marginal and interveinal leaf chlorosis were observed but only in a few Sinapis (6/23 plants) and Sonchus (4/25 plants) species that tested positive for TYLCV; therefore, the presence of symptoms was not consistent with positive or negative results. Most collected Malvaceae spp. had virus-like symptoms such as mosaic, vein clearing, leaf chlorosis, and curling; however, these symptoms were also present in TYLCV-negative plants and they were probably caused by other pathogens or abiotic factors. All the remaining collected plant species did not present discernable symptoms that could be attributed to TYLCV infection.

\section{Discussion}

TYLCV causes significant yield loss in tomato crops in many regions of the world. Native or introduced weed species can be

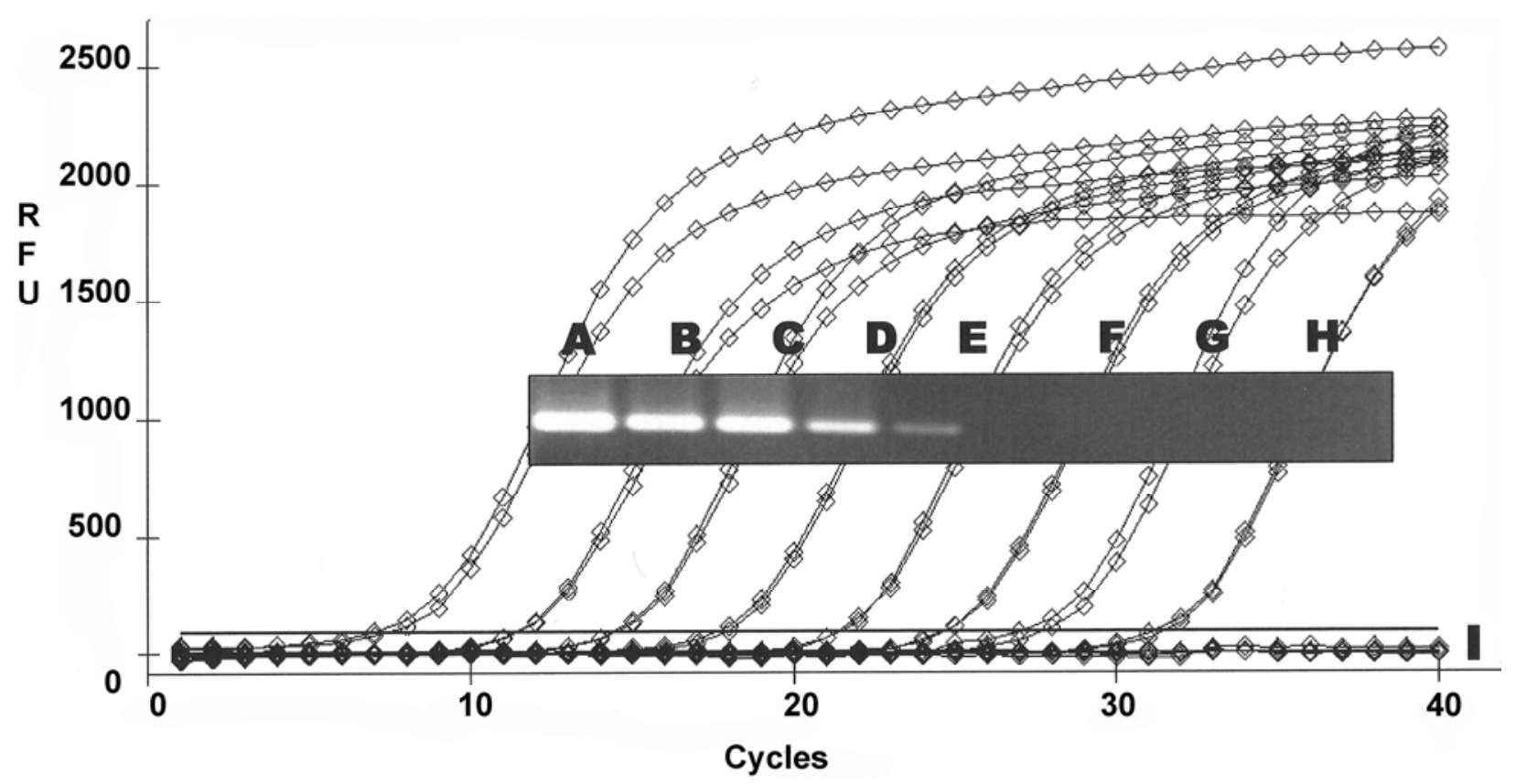

Fig. 1. Sensitivity comparison between real-time (TaqMan) polymerase chain reaction (PCR) and conventional PCR for the detection of Tomato yellow leaf curl virus (TYLCV) using a 10 -fold dilution series of a full-length TYLCV plasmid DNA. A, $10^{-1} \mathrm{ng} / \mu \mathrm{\mu l}$ B, $10^{-2} \mathrm{ng} / \mathrm{\mu l} ; \mathbf{C}, 10^{-3} \mathrm{ng} / \mu \mathrm{l} ; \mathbf{D}, 10^{-4} \mathrm{ng} / \mu \mathrm{l} ; \mathrm{E}, 10^{-5} \mathrm{ng} / \mu \mathrm{l} ; \mathrm{F}, 10^{-6} \mathrm{ng} / \mu \mathrm{l} ; \mathbf{G}, 10^{-7} \mathrm{ng} / \mu \mathrm{l} ; \mathbf{H}, 10^{-8}$ $\mathrm{ng} / \mathrm{Ml}$; and I, negative sample (DNA extract from virus-free tomato plant). 
naturally infected with TYLCV and, thus, serve as potential alternative virus hosts and over-seasoning reservoirs, playing an important role in the disease epidemiology $(7,17,18,32,33)$.

Serological tests (ELISA) detected the virus in less than half of the total species found to be infected by PCR. It is well known that serological tests have had limited success in detecting TYLCV because Begomovirus species are considered to be poor immunogens, yielding low titer antisera due to difficulties in obtaining pure virus preparations. This has made ELISA methods unreliable $(2,3)$. In general, plant extracts from weeds showed a high background OD (approximately 0.15 to 0.25 ) when tested by TAS-ELISA; therefore, in most cases, results were confusing and probably not reliable. Conventional PCR was able to detect TYLCV in most weed species although, in some cases, detection was not clear and barely visible bands were produced in gel electrophoresis. The reasons for the low level of detection in some test plants were likely low virus titer (concentration), secondary compounds such as phenolics, and the abundance of polysaccharides in the extracts $(13,14,24,33)$. A PCR-based, fluorogenic detection method for TYLCV that does not require gel electrophoresis was developed and evaluated. Real-time PCR methodology eliminates any postPCR manipulations and has many advantages over standard PCR because it can be as much as 1,000 times more sensitive, is a rapid and easy-to-perform assay, can easily accommodate large numbers of samples, and eliminates the need for gel electrophoresis and documentation (6).

A number of weed species neighboring or within infected tomato crops were recorded as new hosts of TYLCV in Cyprus based on PCR techniques and sequencing analysis. Previous studies on the TYLCV host range in Cyprus were based on whitefly transmission tests from weeds to tomato plants. Therefore, a plant species was considered to be infected with TYLCV after the virus was transmitted to tomato plants by the whitefly vector, as revealed by development of TYLCV-like symptoms. The previously identified
TYLCV hosts in Cyprus were Asteriscus aquaticus, Calendula arvensis, Chrysanthemum segetum, Urospermum picroides, Lens esculenta, Lotus halophilus, Malva nicaeensis, Plantago lagopus, and D. stramonium (19). These represent only $18 \%$ of the total species found to be infected with TYLCV based on the PCR assays used in the present study (Table 1).

In this study, PCR-based assays showed that many plant species in different families that commonly grow in or near tomato fields harbor TYLCV. In most cases, the infected weeds were asymptomatic. Symptoms that could be associated with TYLCV-infection such as yellowing, leaf curling, and interveinal chlorosis were only observed in some species belonging to the genera of Solanum, Datura, Sinapis, and Sonchus which tested positive (Fig. 2). Association of specific symptoms in weeds with TYLCV infection is challenging. Wild plant species are more genetically diverse than their cultivated counterparts and, therefore, less prone to disease (37). Additionally, changes in vector populations and their host preferences may influence the disease incidence in weeds surrounding the cultivated crops (37). Moreover, the intensity of virus symptoms could be somehow dependent on the development stage at which the plant is infected. The absence of symptoms in plants after virus infection was previously reported for many plant viruses (29), including Begomovirus spp. (19-21,31,33,34).

The incidence of insect-transmitted viruses is generally expected to be related to the abundance of regional vector populations (7). The whitefly Bemisia tabaci is strongly favored by the climate of Cyprus (27) and, as a result, whitefly-associated virus symptoms caused by TYLCV, Tomato chlorosis virus, Cucurbit yellow stunting disorder virus, and Cucumber vein yellowing virus are generally severe. TYLCV secondary hosts such as weeds occurring inside and near tomato crops could serve as important alternative virus reservoirs, contributing significantly to the over-seasoning of the virus and to annual outbreaks. TYLCV-infected species which appear in the field when tomato crops are not present are likely to
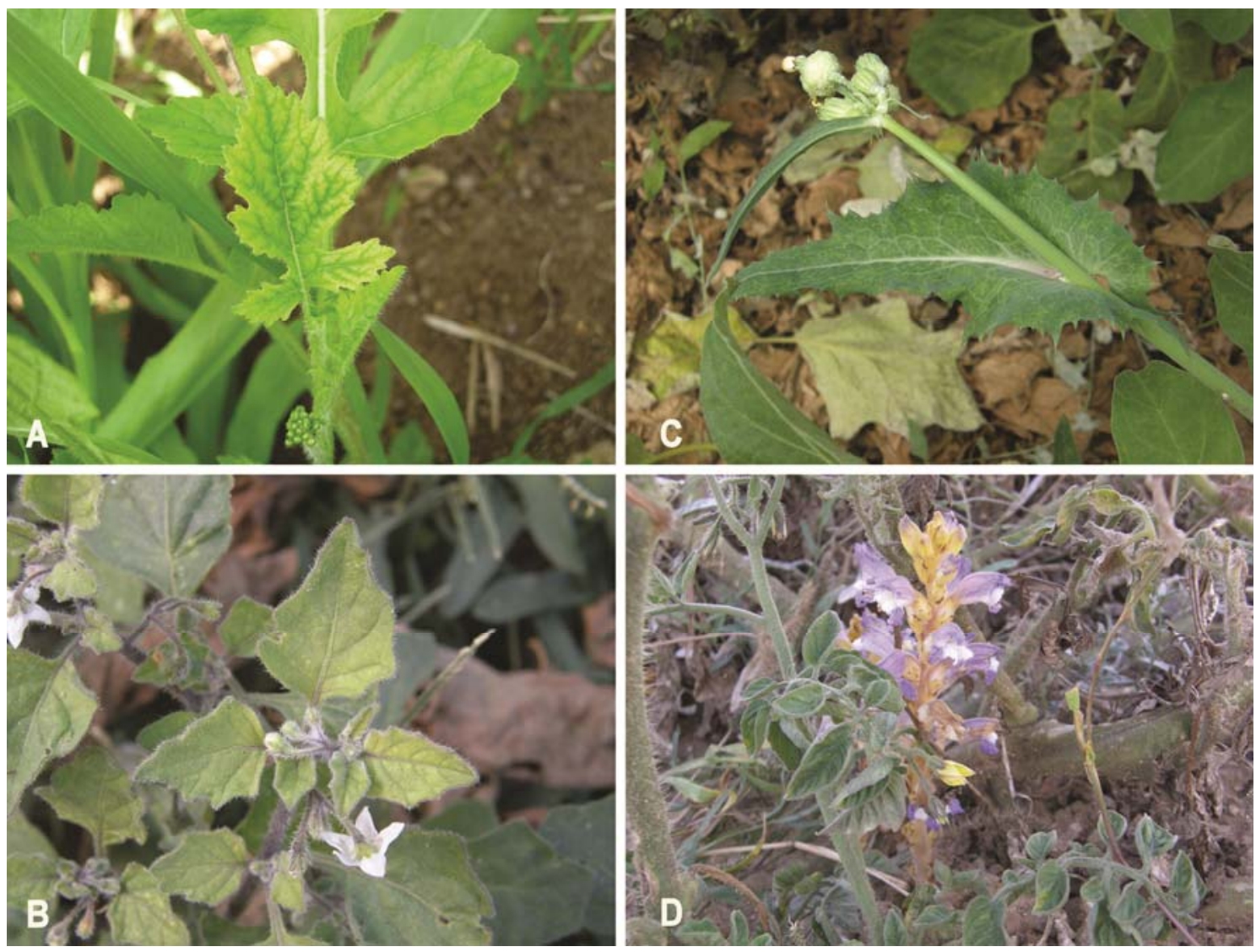

Fig. 2. Disease symptoms within weed species attributed to Tomato yellow leaf curl virus (TYLCV). A, Sinapis alba with leaf yellowing; B, Solanum nigrum with mild leaf curling and chlorosis; C, Sonchus oleraceae showing interveinal chlorosis; and D, Orobanche spp. parasitizing a tomato plant infected with TYLCV. 
be of substantial epidemiological importance because they constitute the only host plants that facilitate virus spread. The role of each of these alternative hosts in the survival and epidemiology of TYLCV during tomato-free periods requires further investigation. Several factors such as $B$. tabaci host preferences, fecundity, population density, and its capacity to efficiently acquire and transmit the virus from the weeds to tomato plants needs to be further studied to understand the role of these reservoir hosts in the epidemiology of TYLCVD.

The new weed species recorded as TYLCV hosts in this study (Table 1) are among the most common weeds in Cyprus, suggesting that the host range of TYLCV in Cyprus (and likely elsewhere) is broader than previously reported. During the past 20 years, most commercial nurseries in Cyprus have been applying hygiene measures required by current plant health laws and statutes for the production of virus-free tomato seedlings. Despite the adoption of a series of management measures against the disease by farmers, including the use of a host-free period during the summer, insecticide spraying, and crop coverage by insect-proof nets, the disease incidence is still high (26). Although previous reports on TYLCV management strategies suggest that the host-free periods have been successful in managing TYLCV in areas with symptomless infected weeds (17), our findings show that, in Cyprus, TYLCV is still the most widespread and economically important virus in tomato crops (26). The relatively high incidence of TYLCV in weeds, together with the high whitefly population density throughout the year on the island, suggest that new management strategies are required that should focus on the use of resistant and tolerant tomato hybrids, removal of infected wild reservoirs, and more effective control of the whitefly vectors. Such measures are expected to result in reduced disease incidence in cultivated fields and, thereby, possibly to reduced vector transmission to cultivated crops from over-seasoning and in-season reservoirs.

\section{Acknowledgments}

This work was funded by the Cyprus Research Promotion Foundation. We thank N. Vouzounis and G. Economides for weed identification; A. Stylianou, A. Hadjinicoli, I. Harkou, D. Anagiotides, Y. Markou, D. Ktorides, K. Hatziafxentis, and A. Savvides for their valuable technical assistance; and A. Kyriakou and M. Stavrinides for critically reviewing this manuscript.

\section{Literature Cited}

1. Accotto, G. P., Navas-Castillo, J., Noris, E., Moriones, E., and Louro, D. 2000. Typing of tomato yellow leaf curl viruses in Europe. Eur. J. Plant Pathol. 106:179-186.

2. Accotto, G. P., and Noris, E. 2007. Detection methods for TYLCV and TYLCSV. Pages 241-249 in: Tomato Yellow Leaf Curl Virus Disease, Management, Molecular Biology, Breeding for Resistance. H. Czosnek, ed. Springer, The Netherlands.

3. Al-Bitar, L., and Luisoni, E. 1995. Tomato yellow leaf curl geminivirus: serological evaluation of an improved purification method. EPPO Bull. 25:267-276.

4. Antignus, Y., and Cohen, S. 1994. Complete nucleotide sequence of an infectious clone of a mild isolate of tomato yellow leaf curl virus (TYLCV). Phytopathology 84:707-712.

5. Bedford, I. D., Kelly, A., Banks, G. K., Briddon, R. W., Cenis, J. L., and Markham, P. G. 1998. Solanum nigrum: an indigenous weed reservoir for Tomato yellow leaf curl geminivirus in southern Spain. Eur. J. Plant Pathol. 104:221-222.

6. Boonham, N., Smith, P., Walsh, K., Tame, J., Morris, J., Spence, N., Bennison, J., and Barker, I. 2002. The detection of Tomato spotted wilt virus (TSWV) in individual thrips using real time fluorescent RT-PCR (TaqMan). J. Virol. Methods 101:37-48.

7. Brown, J. K. 2001. The molecular epidemiology of Begomoviruses. Pages 279-316 in: Trends in Plant Virology. J. A. Khan and J. Dykstra, eds. The Haworth Press, Inc., New York.

8. Brown, J. K. 2007. The Bemisia tabaci species complex: genetic and phenotypic variation and relevance to TYLCV-vector interactions. Pages 25-56 in: Tomato Yellow Leaf Curl Virus Disease, Management, Molecular Biology, Breeding for Resistance. H. Czosnek, ed. Springer, The Netherlands.

9. Cohen, S., and Harpaz, I. 1964. Periodic, rather than continual acquisition of new tomato virus by its vector, the tobacco whitefly (Bemisia tabaci Gennadius). Entomol. Exp. Appl. 7:155-166.

10. Cohen, S., and Nitzany, F. E. 1960. Curly top virus of tomatoes: its identification and mode of transmission. Report No. 311 of the Israeli Plant Protection and Inspection services. (In Hebrew)

11. Czosnek, H., and Latterot, H. 1997. A worldwide survey of Tomato yellow leaf curl viruses. Arch. Virol. 142:1391-1406.

12. Dellaporta, S. L., Wood, V. P., and Hicks, J. B. 1983. A plant DNA minipreparation: version II. Plant Mol. Rep. 1:19-21.

13. Demeke, T., and Adams, R. P. 1992. The effect of plant polysaccharides and buffer additives in PCR. Biotechniques 12:332-334.

14. Dovas, C. I., and Katis, N. I. 2003. A spot multiplex nested RT-PCR for the simultaneous and generic detection of viruses involved in the etiology of grapevine leafroll and rugose wood of grapevine. J. Virol. Methods 109:217-226.

15. Gal-On, A., Naglis, A., Leibman, D., Ziadna, H., Kathiravan, K., Papayiannis, L., Holdengreber, V., Guenoune-Gelbert, D., Lapidot, M., and Aly, R. 2009. Broomrape can acquire viruses from its hosts. Phytopathology 99:1321-1329.

16. García-Andrés, S., Monci, F., Navas-Castillo, J., and Moriones, E. 2006. Begomovirus genetic diversity in the native plant reservoir Solanum nigrum: evidence for the presence of a new virus species of recombinant nature. Virology 350:433-442.

17. Gilbertson, R. L., Rojas, M. R., Kon, T., and Jaquez J. 2007. Introduction of Tomato yellow leaf curl virus into the Dominican Republic: the development of a successful integrated pest management strategy. In: Tomato Yellow Leaf Curl Virus Disease, Management, Molecular Biology, Breeding for Resistance. Springer, The Netherlands.

18. Ioannou, N. 1985. Yellow leaf curl and other virus diseases of tomato in Cyprus. Plant Pathol. 34:428-434.

19. Ioannou, N. 1987. Cultural management of tomato yellow leaf curl disease in Cyprus. Plant Pathol. 36:367-373.

20. Jorda, C., Font, I., Martinez, P., Juarez, M., and Ortega, A. 2001. Current status and new natural hosts of Tomato yellow leaf curl virus (TYLCV) in Spain. Plant Dis. 85:445.

21. Kashina, B. D., Mabagala, R. B., and Anatolia, A. 2002. Molecular characterization of isolates of Tomato yellow leaf curl from Tanzania. Arch. Phytopathol. Plant Prot. 35:255-267.

22. Martinez-Culebras, P. V., Font, I., and Jorda, C. 2001. A rapid PCR method to discriminate between Tomato yellow leaf curl virus isolates. Ann. Appl. Biol. 139:251-257.

23. Navas-Castillo, J., Sánchez-Campos, S., Díaz, J. A., Sáez-Alonso, E., and Moriones, E. 1999. Tomato yellow leaf curl virus-Is causes a novel disease of common bean and severe epidemics in tomato in Spain. Plant Dis. 83:29-32.

24. Osman, F., and Rowhani, A. 2006. Application of a spotting sample preparation technique for the detection of pathogens in woody plants by RT-PCR and real-time PCR (TaqMan). J. Virol. Methods 133:130-136.

25. Papayiannis, L. C., Brown, J. K., Hadjistylli, M., and Katis, N. I. 2008. Bemisia tabaci biotype B associated with tomato yellow leaf curl disease epidemics in Rhodes Island, Greece. Phytoparasitica 36:20-22.

26. Papayiannis, L. C., Brown, J. K., Idris, A. M. Paraskevopoulos, A., and Katis, N. I., 2009. Epidemiology and characterization of Begomovirus and Bemisia tabaci biotypes in Greece and Cyprus. Phytopathol. Mediterr. 48:320

27. Papayiannis, L. C., Brown, J. K., Seraphides, N. A., Hadjistylli, M., Ioannou, N., and Katis, N. I. 2009. A real-time PCR assay to differentiate the B and Q biotypes of the Bemisia tabaci complex in Cyprus. Bull. Entomol. Res. 99:573-582.

28. Papayiannis, L. C., Paraskevopoulos, A., and Katis, N. I. 2007. First report of Tomato yellow leaf curl virus infecting common Bean in Greece. Plant Dis. 91:465.

29. Powell, C. A., Forer, L. B., Stouffer, R. F., Cummins, J. N., Gonsalves, D. Rosenberger, D. A., Hoffman, J., and Lister, R. M. 1984. Orchard weeds as hosts of tomato ringspot and tobacco ringspot viruses. Plant Dis. 68:242-244.

30. Reina, J., Morilla, G., Bejarano, E. R., Rodriguez, M. D., and Janssen, D. 1999. First report of Capsicum annuum plants infected by tomato yellow leaf curl virus. Plant Dis. 83:1176.

31. Rojas, M. R., Kon, T., Natwick, E. T., Polston, J. E., Akad, F., and Gilbertson, R. L. 2007. First report of Tomato yellow leaf curl virus associated with tomato yellow leaf curl disease in California. Plant Dis. 91:1056.

32. Roye, M. E., Wernecke, M. E., McLaughlin, W. A., Nakhla, M. K., and Maxwell, D. P. 1999. Tomato dwarf leaf curl virus, a new bipartite geminivirus associated with tomatoes and peppers in Jamaica and mixed infection with tomato leaf curl virus. Plant Pathol. 48:370-378.

33. Salati, R., Nahkla, M. K., Rojas, M.R., Guzman, P., Jaquez, J., Maxwell, D. P., and Gilbertson, R. L. 2002. Tomato yellow leaf curl virus in the Dominican Republic: characterization of an infectious clone, virus monitoring in whiteflies, and identification of reservoir hosts. Phytopathology 92:487-496.

34. Sanchez-Campos, S., Navas-Castillo, J., Camero, R., Soria, C., Diaz, J. A., and Moriones, E. 1999. Displacement of Tomato yellow leaf curl virus (TYLCV)-Sr by TYLCV-Is in tomato epidemics in Spain. Phytopathology 89:1038-1043.

35. Thompson, J. D., Gibson, T. J., Plewniak, F., Jeanmougin, F., and Higgins, D. G. 1997. The ClustalX windows interface: flexible strategies for multiple sequence alignment aided by quality analysis tools. Nucleic Acids Res. 24:4876-4882.

36. Varma, A., and Malathi, V. G. 2003. Emerging geminivirus problem: a serious threat to crop production. Ann. Appl. Biol. 142:145-164.

37. Wisler, G. C., and Norris R. F. 2005. Interactions between weeds and cultivated plants as related to management of plant pathogens Weed Sci. 53:914-917. 